\title{
Management Accounting Research and Structuration Theory: A Critical \\ Realist Critique
}

\section{Introduction and Background}

Giddens' $^{1}$ structuration theory has long been a popular theoretical lens for management accounting researchers, especially in the area of management accounting change. ${ }^{2}$ Since the publication of Robert and Scapens ${ }^{3}$ and Macintosh and Scapens, ${ }^{4}$ which introduced structuration theory to accounting researchers, many structuration-inspired articles have been published in accounting journals. Recently, there has been a renewed interest in evaluating the achievements and potentials of the theory in extant accounting research. ${ }^{5}$ However, we feel that these evaluations in accounting research do not seem to fully engage with the fundamentals of structuration theory. ${ }^{6}$ The aim of this paper is to fill this gap.

Recent works by Englund and Gerdin ${ }^{7}$ and Englund et al., ${ }^{8}$ have carried out a comprehensive evaluation of structuration theory inspired accounting studies. Englund et al., have summarised the achievements of structuration in accounting studies. Two major contributions are notable. First, the structuration theory has made a significant contribution to 'alternative' accounting research which offers challenges to a rational/positivist view of accounting. Second, it also offers an alternative to the more structure or agency centric accounting research and provides us with richer explanations of accounting change especially management accounting change. In their

\footnotetext{
1 1976, 1979, 1981, 1984.

2 Baxter and Chua, 2003.

${ }^{3} 1985$.

41990.

${ }^{5}$ Jack and Kholeif, 2008; Coad and Glyptis, 2014; Roberts, 2014.

${ }^{6}$ Boland, 1993.

7 2008, 2014.

${ }^{8} 2011$.
} 
evaluations, Englund and his colleagues offer two areas for improvement for accounting researchers applying Giddens' structuration theory. The first, as Englund and Gerdin ${ }^{9}$ highlighted, is the inconsistencies that are apparent in the conceptualisation of 'structure' in structuration-inspired accounting literature. The second is the failure of accounting studies to appropriate the structuration theory as a whole. Most studies seem to have adopted a research strategy of using one or more concepts as a 'sensitizing device' for empirical research. Englund et al. ${ }^{10}$ also argued that the structuration theory's potential to contribute to accounting research remains untapped perhaps due to the research strategy adopted by structuration-based accounting researchers.

The above critique tends to focus on how accounting researchers interpreted or used fundamentals of structuration theory but fell short of critiquing structuration theory itself. We wish to extend this debate by identifying the underlying reasons for the apparent weaknesses in structuration theory-inspired accounting research. Whilst Giddens should not take responsibility for how accounting researchers have interpreted and applied his concepts in explaining accounting phenomena, we argue that the roots of these weaknesses perhaps lie in structuration theory itself, rather than in its use by accounting researchers. Giddens' structuration theory has been subject to severe criticisms by contemporary sociologists, ${ }^{11}$ but these criticisms are rarely echoed in the accounting literature. Thus, this paper aims to draw accounting researchers' attention to these criticisms. More specifically, the paper seeks to extend the critique of structuration theory from a 'critical realist' perspective, ${ }^{12}$ in particular by demonstrating how these theoretical Achilles' heels manifest in management accounting research. We do not wish to

\footnotetext{
92008.

${ }^{10}$ Englund et al. 2011, p.14.

${ }^{11}$ Porpora, 1989; Thompson, 1989; Archer, 1982, 1995.

${ }^{12}$ Bhaskar, 1979, 1997.
} 
discount the empirical and theoretical contributions made by structuration-based accounting studies, but merely highlight what accounting researchers may have missed in using this theoretical lens.

In order to underscore what accounting researchers might have neglected by embracing a structuration lens, we conduct an intensive examination of one of the most cited structurationbased accounting studies, namely, Macintosh and Scapens ${ }^{13}$ (hereafter M\&S) and trace the same limitations in other more recent structuration based accounting studies. We note that this paper mainly focuses on one seminal and a few other recent papers to illustrate the potential weaknesses of structuration theory for a deeper understanding of management accounting change. Whilst acknowledging the limitations ${ }^{\mathrm{i}}$ of using one or few papers to offer a comprehensive critique of theoretical applications, we feel that this is less of a concern for us for two reasons. First, we are situating our paper in the context of limitations identified in the recent comprehensive review of structuration-based accounting studies ${ }^{14}$. Second, the critique is of fundamental nature primarily associated with the theory itself instead of accounting studies. In their paper, $M \& S^{15}$ analysed the empirics of an earlier case study by Covaleski and Dirsmith, ${ }^{16}$ using the structuration theory. We have reanalysed the case using a broad critical realist framework, as suggested by Sayer ${ }^{17}$ and Archer, ${ }^{18}$ and have proposed a way forward.

This paper has three main sections. First, it briefly describes the various conceptualisations of structure and agency commonly used in the sociological literature, drawing attention to Giddens' conceptualisation of structure and agency and explaining an alternate critical realist

\footnotetext{
131990.

${ }^{14}$ Englund and Gerdin, 2011 and 2014.

151990.

161998.

171992.

181995.
} 
interpretation of structure and agency. This is followed by an in-depth discussion of structuration theory and management accounting research through an examination of $M \& S^{19}$, tracing the inherent limitations of structuration theory in this seminal paper. This section also relates the limitations identified in M\&S to other, more recent, structuration-based accounting research papers. In the final section, the paper suggests a way forward by re-examining the case study used by $M \& S$ through a critical realist lens, ${ }^{20}$ thus setting out new avenues for management accounting research. The final section concludes the paper.

\section{Agency, Structure, and Structuration: A Critical Realist Critique}

Different schools of thought have held various positions regarding the age-old sociological debate over structure and agency. This debate has also influenced management accounting research. ${ }^{21}$ Giddens' structuration theory is one of many theories that have contributed to this debate. These different conceptualisations of agency and structure, including structuration theory, are briefly discussed below. Furthermore, drawing on Porpora's (1989) classification scheme, the paper briefly presents a critical realist critique on agency and structure-centric studies and structuration.

\section{Agency-Centric}

According to this school of thought, structure is no more than an abstraction of repetitive individual behaviour. ${ }^{22}$ Generally speaking, interpretive research in accounting falls into this category. ${ }^{23}$ The main criticism with this approach is that any sociological explanation inevitably

\footnotetext{
191990.

${ }^{20}$ Bhaskar, 1979 and 1997; Sayer, 1992; Archer, 1995.

${ }^{21}$ Kilfoyle and Richardson, 2011.

22 Porpora, 1989.

${ }^{23}$ Dent, 1991; Mourtisen, 1999.
} 
entails a particular societal context: ${ }^{24}$ taking an exam assumes an educational system, and cashing a cheque assumes a banking system. Individualists' response to this is that the social context of individuals comprises nothing but other individuals, along with their motives, dispositions, beliefs, and resources. This is an inadequate defence for many, including critical realists, ${ }^{25}$ as individualists tend to deny the existence of properties that emerge when individuals form a collectivity. This concept of structure gives primacy to agency and makes structure an epiphenomenon —an approach which $\operatorname{Archer}^{26}$ has called 'upward conflation'.

This upward conflation is evident in the treatment by interpretive research of the 'conflict' which inevitably arises in management accounting changes. ${ }^{27}$ In such research, the actors struggle to pursue interests subjectively determined by them in a relatively 'free floating' manner. Armstrong ${ }^{28}$ criticised interpretive management accounting change research for its exclusive focus on social interaction. The social interactions, he argued, are the structural conditions under which the interaction takes place and below is the subjectivity of individuals, which is itself shaped by what is above. ${ }^{29}$

\section{Structure-Centric}

According to this paradigm, when individuals combine to form collectivities (organisations, societies, etc.), these collectivities have more properties than the sum of their parts. Properties of collectivities, such as belief systems, the degree of integration, and suicide rates, are assumed to be 'things' or 'social facts' and are the objects of scientific study. Therefore, to investigate these

\footnotetext{
${ }^{24}$ Kakkuri-Knuutilla et al., 2008.

25 Sayer, 1992; Archer, 1995.

${ }^{26} 1995$.

${ }^{27}$ see, e.g., Covaleski and Dirsmith, 1986, 1988; Mourtisen, 1999.

282008 .

${ }^{29}$ Armstrong, 2008.
} 
collectivities, the focus should not be on individuals, but on the properties of these collectivities. The objective of social science should be to discover regularities (regular connections) between the properties of a collectivity such as suicide rates and the degree of social integrity, the idea of which is to develop 'social physics'.

A good example of this genre of research is contingency-based management accounting research, in which different organisational variables, such as firm size, industry affiliation or technology, are correlated with management accounting variables such as the flexibility of a performance-measurement system or 'top-down' budgeting system. ${ }^{30}$ Based on a cross-sectional analysis of firms, researchers confirm or refute a law, for example, large firms are more likely to have more formal budgeting systems, whereas firms operating in an uncertain environment are likely to have a flexible performance-measurement system; or alternatively, firms pursuing a 'differentiation' strategy focus more closely on the customer satisfaction aspect of the performance scorecard, etc. If we are to believe in these laws, we must first believe that large firms affect individuals in a law-like way and that these individuals, in turn, design 'bottom-up' budgets in a law-like manner. Be that as it may, treating structure as a law-like regularity between social facts treats agency as an epiphenomenon—which $\operatorname{Archer}^{31}$ has called 'downward conflation'.

\section{Critical Realist Position on Structure and Agency}

The concept of structure as a system of relationships between positions is most famously associated with the Marxist tradition in terms of the relationship between classes in various modes of production. ${ }^{32}$ However, this concept has been extended and refined by critical realists

\footnotetext{
${ }^{30}$ Chenhall, 2003.

31 1995.

${ }^{32}$ Porpora, 1989.
} 
such as Bhaskar, ${ }^{33}$ Outhwaite, ${ }^{34}$ and Archer $^{35}$. In this approach, social structure is a system of internally and necessarily related objects (or positions). Two objects are internally and necessarily related if the two (or one of the two) cannot exist without the other. Examples of internally and necessarily related social objects include father/mother/children, capitalist/labour/managers, etc. When two or more social objects combine to form a structure, these structures have emergent properties, i.e., the properties of structures cannot be reduced to those of individual objects/positions. A typical example from nature is hydrogen and oxygen combining to form water, which has emergent properties. ${ }^{36}$

In social science, bureaucracy (a structure arising out of internal and necessary relations between positions) has the emergent power to work efficiently, an emergent property that cannot be reduced to the individuals constituting the structure. ${ }^{37}$ Similarly, the properties and powers belonging to a landlord or tenant cannot be reduced to the individuals in this structure. Those individuals who are incumbent in structures have their own powers and properties such as reflection, designing projects (including projects to change the structures they inhabit), articulation, and organisation for the pursuit of projects. There is, thus, a clear distinction between the power of structures (internally related positions) and the power of agents (the individuals who occupy these positions).

Structure influences agents by giving them powers, constraints, and vested interests. Agents occupying structural positions, therefore, have a vested interest in either preserving the structural condition (usually if they are in a position of relative advantage) or trying to change it (usually if

\footnotetext{
331997.

341987.

351995.

${ }^{36}$ Sayer, 1992.

37 Sayer, 1992.
} 
they are in a position of relative disadvantage). Every structural position exercises certain powers or constraints over its occupants. These structural constraints and powers are not a figment of the incumbents' imaginations, but are real. Critical realists, thus, believe in a reality independent of agents' beliefs. Agents' intents and beliefs may be important causes of their actions, and thus hermeneutics occupies an important place in critical realist theory. However, agents form these beliefs and intents while occupying certain structural positions, and thus the study of social phenomena requires the study of each (structure and agency) separately. This analytical separation of structure and agency is called analytical dualism and is a hallmark of critical realism. ${ }^{38}$

\section{Structuration}

The postmodernist turn in social theory resulted in the emergence of various alternatives to address the issue of structure and agency. The structuration theory proposed by British sociologist, Anthony Giddens, is one of those alternative approaches. Giddens ${ }^{39}$ suggested that individual human agency and social structure are mutually dependent. Social structures do not exist independently of human agency: they are both constituted by human agency and, at the same time, are the very medium of this constitution, a concept that Giddens calls 'duality'. According to Giddens ${ }^{40}$ structure is basically memory traces in the minds of actors in the form of rules and resources. ${ }^{41}$ These rules and resources are instantiated by the agent only when action takes place, and thus they structure behaviour. Giddens suggested that every action involves human agency as well as the instantiation of structures (i.e., rules and resources in the heads of actors), thus forming a 'duality'.

\footnotetext{
38 Archer, 1995.

39 1976, 1979, 1981 and 1984.

401984.

${ }^{41}$ Giddens, 1981:26.
} 
For Giddens, agency and structure operate simultaneously and recursively in the actions of agents, depending on how we look at the action. If we look at one side, we see structure; if we look at the other side, we see human agency. ${ }^{42}$ Rules include the agent's perceptions of morality, i.e., what is right and wrong (legitimation structure), and semantic rules, i.e. what does 'this' mean (signification structure), as well as the resources that the agent perceives him or herself to possess vis-à-vis other agents (domination structure). Domination structures are also characterized by the 'dialectic of control'. As Giddens explains, "Power relations are always two-way, that is to say, however subordinate an actor may be in a social relationship, the very fact of involvement in that relationship gives him or her a certain amount of power over the other." 43

Nevertheless, many contemporary sociologists, especially critical realists, have raised significant theoretical concerns to 'duality' and 'structuration'. The most significant issue, according to critical realists, is not to give due importance to the material conditions which precede and condition human action. ${ }^{44}$ Thompson ${ }^{45}$ explains, "When a school leaver is faced with the choice of joining a youth training scheme or signing on the dole, the constraints which operate are not simply those of comprehensibility or sanctioning. For it is the range of alternatives, which is restricted, and these restrictions do not stem from semantic and moral rules but from structural conditions for the persistence (and decline) of productive institutions".

Not treating the material conditions on agents analytically have led to two major concerns with respect to Giddens' conceptualisation of agency as argued by critical realists. First, in the absence of separate analyses of material conditions, the power of human agency tends to be over-

\footnotetext{
${ }^{42}$ Archer, 1995.

${ }^{43}$ Giddens, 1979, p.6.

44 Thompson, 1989; Archer, 1992.

45 1989:72.
} 
emphasised. Giddens stresses that, at any point in time, the agent "could have done otherwise" and "an agent who has no option to [act otherwise] is not an agent". ${ }^{46}$ However, factory workers and low-level white-collar employees with declining bargaining power in a sluggish economy know that their ability to act otherwise is a luxury they can hardly afford. Thompson ${ }^{47}$ suggests that, contrary to Giddens' characterization, some agents happen to be in a position that offers more options than others, but even then they may come across constraints external to their perceptions of meanings and morality, leaving them with only one option. We need to acknowledge that some sympathetic readings of Giddens' provided strong defence against the above critique as will be discussed later. ${ }^{48}$

The second concern is the motivation of agents in the absence of proper considerations to prior material conditions. ${ }^{49}$ Critical realist accounts of positions and their inter-relationship incorporate interests that are bundled together in 'positions'. These interests furnish agents occupying those positions with the motivation to act in a certain manner. For example, a capitalist structure provides capitalists with a position of interest and power (and hence motivation) to make more profit.

Furthermore, Giddens' insistence on virtual structures, i.e., rules and resources, has also raised further concerns from critical realist perspectives. While it is to some extent understandable that some rules may have a virtual status, resources clearly do not belong to the virtual realm. Sewell,${ }^{50}$ recognising this problem, has suggested an amendment to structuration theory, that is,

\footnotetext{
${ }^{46}$ Giddens, 1984, quoted in Thompson, 1989:73.

471989.

${ }^{48}$ Stones, 2005, Cohen, 1989

49 Archer, 1995.

501992.
} 
resources belong to the physical realm and rules belong to the virtual realm. However, assigning a physical status to resources means acknowledging that structures are $a$ priori and material, two conditions which run contrary to the very spirit of structuration theory. ${ }^{51}$

While the virtual or physical status of resources in structuration theory is problematic in its own right, Archer (1995) raises questions about the virtual status of rules. Most rules of importance to our day-to-day lives are codified (laws, standards, etc.); they are not memory traces in the heads of agents, but rather are written in books, manuals, and journals and hence, can be described as 'contents of libraries'.52 These rules, like material structures, condition and precede agents' actions. They also have an existence independent of their reception and interpretation by agents. According to Archer ${ }^{53}$, knowing, interpreting, or following the rules comes later (in Archer's terms, at time T2) and is the domain of human agency.

Critical realists ${ }^{54}$ have also raised concerns about the apparent lack of a temporal dimension in the relationship between structure and agency. As Giddens considers action and structure to be coterminous, he does not "acknowledge that structure and action work on different time intervals (however small the gap between them)". ${ }^{55}$ The argument is that any value that we could have derived from these two concepts being separate in the first place is lost. ${ }^{56}$ Giddens ${ }^{157}$ approach, in which the two concepts are linked with each other, is described by $\operatorname{Archer}^{58}$ as "central conflation'.

\footnotetext{
51 Archer, 1995.

52 Archer, 1995.

531995.

${ }^{54}$ Archer 1982, 1995.

${ }^{55}$ Archer, 1982:467.

${ }^{56}$ Stones, 2005:52.

571984.

581995.
} 
It is important to note that in the face of strong criticism from critical realist scholars, Stones and others $^{59}$ defended structuration theory, especially against the central criticisms i.e. conflation of structure and agency. Stones argued that Giddens duly acknowledged the pre-existence of material conditions on agents but a lack of emphasis on those conditions in structuration theory perhaps led the critics to misinterpret the theory. In their attempts to clarify aspects of structuration theory, both Cohen and Stones, drawing from Giddens' notion of "position-practice relations", extended the structuration theory. Stones' strong structuration theory argued for a distinction between external structures (as represented by position-practice relations-and containing many of the "real" attributes of structures recognised by critical realists) and internal structures ('virtual' structures in accordance with Giddens' definition). In this move, Stones incorporated both duality and dualism in his 'stronger' model of structuration. According to Stones, dualism and duality should not be seen as mutually exclusive notions. Instead they should be used as complementary conceptual resources useful for concrete social analysis. Without going into the details of 'stronger' structuration theory ${ }^{60}$ or its criticisms, we will say that the distinguishing feature of structuration theory is 'duality'. Incorporating dualism by importing external material structures in structuration theory strips structuration theory of its very identity ${ }^{61}$.

\footnotetext{
${ }^{59}$ Stones, 2001, Cohen, 1989

${ }^{60}$ Stones, 2001

${ }^{61}$ Spaargaren and Mommaas, 2006
} 
Having described the debate on structure, agency and structuration, it is useful for the readers to see what critical realism, as opposed to structuration theory, might offer in conceptualising and understanding management accounting change.

\section{[Insert Table 1]}

Table 1 offers the potential differences between structuration and critical realism when it comes to studying accounting changes. The table, in particular, demonstrates key theoretical differences in conceptualisation, continuation, and change of accounting practices. These elements will be the basis of our discussions about structuration-inspired management accounting studies, in particular, M\&S. ${ }^{62}$ This is to highlight what might have been missed by accounting researchers by embracing structuration theory.

\section{Structuration-based Accounting Studies: A Critical Realist Critique}

Over the last twenty-five years, accounting scholars have used structuration theory extensively to explain management accounting practices and change. ${ }^{63}$ These include both conceptual/methodological papers ${ }^{64}$ and empirical papers. ${ }^{65}$ In order to investigate the theoretical problems inherent in structuration theory and its influence on explanations of management accounting practice and change, we have selected few recent studies and one of the most influential papers in this genre of research - M\&S. ${ }^{66}$ The seminal nature of this paper is evident from its extensive quotation, ever since its publication, in accounting papers adopting structuration theory. Using structuration theory, $M \& S^{67}$ reframed the empirics of a field study

\footnotetext{
621990 .

63 Baxter and Chua, 2003.

${ }^{64}$ Boland, 1993; Englund and Gerdin, 2008; Englund et al., 2011.

${ }^{65}$ Macintosh and Scapens, 1990; Uddin and Tsamenyi, 2005.

661990.

${ }^{67} 1990$.
} 
originally published by $C \& D^{68}$. Their objective was to demonstrate the value of structuration theory for management accounting research. In order to understand how management accounting has been conceptualised in terms of structuration theory, it is important briefly to revisit the empirics of the original paper.

\section{Macintosh and Scapens (1990)}

The original paper by $C \& D$ is a longitudinal case study about a budget row between the University of Wisconsin and the state governor. The case describes the original budget allocation mechanism, its rationale, the change processes therein, and its final shape, covering the actions of various actors and social discourses. The University of Wisconsin used to receive its annual budget from the state on the basis of an enrolment funding formula (EFF). The state used this formula to allocate funds to all state institutions in the areas of instruction, library, and educational programs. The EFF was a mechanism that provided the state with an 'objective' and 'rational' basis for funding various state institutions. This was especially important given the scientific management discourse that had prevailed in the state since the turn of the century. This discourse entailed that the state should run its various institutions according to strict scientific management principles, leaving aside politics.

Once the budget was allocated, the state government would leave it to the university administration to allocate funds to various campuses and programs. This allowed the university to retain administrative autonomy while presenting a rational face to outsiders. This arrangement worked to the mutual satisfaction of both parties until budget allocations to all state agencies began to decline because of an economic downturn. This scarcity of resources triggered tensions

\footnotetext{
681988.
} 
between various campuses within the university. The prestigious Madison campus started to feel that it was not being allocated sufficient resources, whereas other campuses started to feel that the university's central management was giving too much importance to Madison.

Under these circumstances, in submitting its 1983-85 budget, the University of Wisconsin abandoned the traditional EFF format and instead submitted its budget to the administration department in a new format, which involved asking for specific budget amounts against three broad categories called 'decision item narratives': modernization of laboratory and instructional equipment, student demand for professional programs (business, maths, etc.), and better access to library resources. These decision narratives were supported by specific examples and expressions by the deans regarding their needs, thus giving the process a new form of 'rationality'.

In order to gain external social support, the university promoted the idea that an increased resource flow to the university would help the state out of the economic recession. However, the university was still trying to retain autonomy in terms of internal allocations by not linking the decision narratives (DINs) with specific campuses or programs. The governor, the administration department, and the legislative fiscal bureau were unimpressed by this move by the university's management. First, the EFF was seen as an age-old, agreed, 'rational' and 'objective' measure for allocating resources to various state agencies. Second, it forced the government to choose between different elements such as laboratory, library or equipment. In order to avoid this complicated choice between alternatives, the administration department merged the three categories into one and recommended to the legislative fiscal bureau more than eighty percent of the budget amount sought by the university. 
It was a win-win situation because the university received significant funding while the government did not have to accept the rationality of a different budget format. In addition to the budget sought by the university, the governor allocated more funding, one million US dollars, for retention of the star faculty, which received considerable media coverage. However, later, when the university submitted its faculty remuneration budget to the Joint Commission for Economic Resources asking for additional funding for faculty salaries, it was declined by the government.

The general feeling, according to $C \& D$, was that the governor had beaten the university in the budget game, having received publicity for approving a generous budget to the university, which in the end, was effectively paid for by the university faculty. The thrust of C\&D's paper was to demonstrate the social and political side of accounting and so illustrate that accounting is a social practice rather than a technical phenomenon. They claimed that it creates reality by making certain aspects of organisational life important and others trivial; it gives a rational and objective appearance to political and subjective managerial decisions and is itself uniquely implicated in changes to societal values.

The objective of M\&S was to illustrate the usefulness of structuration theory; hence, they reframed the empirics of the case in terms of structuration theory. According to M\&S, the EFFbased budgeting practice stemmed from a 'signification structure' of rationality, neutrality, and objectivity and the practice itself reproduced the structure, thus forming a 'duality'. ${ }^{69}$ In addition to a signification structure, the EFF budgeting system drew on and reproduced a legitimation structure as well as power structures, thus reflecting structuration in all three aspects of structure. M\&S also highlighted other concepts of structuration theory reflected in the empirics of the case. For example, the EFF-based budget provided the state with power resources over the university,

\footnotetext{
${ }^{69}$ p.464.
} 
while at the same time, the university had certain resources in terms of the budgetary information it possessed. According to $M \& S$, this budget battle between state and university illustrated Giddens' concept of dialectic of control.

M\&S also contended that shortage of funds resulted in the creation of a crisis situation (in contrast to the routine situation prevailing before the shortage) in which the agency of the university management came to the forefront in an effort to dislodge existing structures of meaning, legitimation, and power. The university tried to change the legitimation and meaning structures by using the resources available to it, in terms of increased operational information about the university and access to the media and civil society. The governor used his authoritative resources to merge the three categories into one, thus avoiding treading on dangerous ground. The governor and other state departments used existing signification structures to question the actions of the university, which the university called irrational. However, to appease the university and civil society, the governor used his allocative resources to fund, on this occasion alone, more than eighty percent of the budget requested. These actions by the state counteracted the challenge mounted by the university questioning the prevalent meaning and legitimation structures, which resulted in unintended consequences in terms of the governor using his allocative resources to freeze the faculty salary budget at the current level.

Drawing from this case study and linking management accounting to structuration theory, $M \& S$ contended that management accounting is involved as a virtual modality (in Giddens' terms) visà-vis all three structures. In terms of meaning structures, it is an interpretive scheme used by organisational players to make sense of organisational activities. Management accounting is used as a norm to draw on legitimation structures to determine good and bad practices, as well as the sanctions and rewards that should be associated with these good and bad practices. Lastly, in 
power structures, management accounting is used as a resource by organisational actors to hold others accountable.

While very insightful, we would argue that the application of structuration theory seemingly under appreciates some significant issues critical to the budgetary process in C\&D's case. To begin with, there is the issue of the existence of prior material structural conditions in the form of the economic downturn in the State of Wisconsin, which limited the choices available to the actors on the scene including the choices to act otherwise. ${ }^{70}$ For example, the state could not allocate the amount of funds that it wished to allocate to state agencies, and in a constrained funding situation, the university could not spend the amount it desired on various programs and campuses. These restrictions did not stem from semantic and moral rules but from a priori material structural conditions. Lesser focus on material conditions is clearly evident in $M \& S$ version of the case perhaps driven by theoretical weaknesses even acknowledged by proponents of the structuration theory (Stones, 2001).

Similarly, looking at the empirics of the case, Macintosh and Scapens ${ }^{171}$ equation of management accounting with a virtual modality is also a problematic claim (see the earlier discussion of the virtual status of 'rules'). It is unclear from this case study how management accounting can be considered virtual. It is apparent from the case that there were detailed, documented accounting rules and regulations (e.g., EFF) governing the preparation of state and university budgets; these existed in university and state policy and procedure manuals, rather than in the minds of the actors involved. The budgeting rules and regulations existed independently and preceded the sequence of interactions that took place between the agents in the case study. The agents in the

\footnotetext{
70 Thompson, 1989.

${ }^{71} 1990$.
} 
case study tried to change or defend these accounting rules and regulations, which establishes that these management accounting rules were independent of and preceded the sequence of interactions and had a conditioning influence on the actions of the agents. It is not surprising that M\&S viewed management accounting as a virtual modality existing only in the minds of the actors and manifested only at the time of the action. This was in line with Giddens' own example of language as a virtual structure which conditions agency, i.e., 'speaking the language', and at the same time, is an outcome of the act of speaking the language. Acceptance of the a priori existence of ideas and rules outside the minds of actors is a position that does not fit in with the basic tenets of structuration theory. Codified rules like accounting have a clear locus of existence in books and manuals. However, giving independent ontological status to these ideas would have meant bringing in the former idea of 'dualism', which is unacceptable to proponents of 'duality'.

\section{Structuration-based Accounting Research}

Given that issues identified in the $M \& S$ paper above are mainly about basic tenets of structuration theory, they are more or less present in other structuration-based accounting research including relatively recent papers utilizing the theory. The most important problem, as identified above, is the lack of due consideration given to the existence of material structures and their causal effect on the actions of incumbents, which is visible in almost all accounting studies that use structuration as a theoretical lens. ${ }^{72}$ Englund et al. and Englund and Gerdin, in which they took stock of all accounting papers published till 2014 employing structuration theory, argue: some accounting studies, like $M \& S$, conceptualise accounting as a virtual modality; while others consider it non-virtual i.e., empirical rules and regulations. Nevertheless, Englund et al. attributed the issue of conflation to the misinterpretations/misreadings of Giddens' structuration

\footnotetext{
${ }^{72}$ Granlund, 2001; Conrad, 2005; Hassan, 2010.
} 
theory by accounting researchers. We would like to argue perhaps the problem lies with the theory itself. We will consider this drawing on some accounting studies below.

We would argue 'Agency-related problems', namely, exaggerated power of agents and their lack of motivation, arising from the denial of material structures is evident in structuration-based accounting research. For example, on the issue of the 'power of agents to act otherwise', the main findings of Jayasinghe and Thomas ${ }^{173}$ structuration theory-based paper is quite revealing. They claimed, "[t]he case study suggests that it is the strongly prevailing patronage based political system, as mobilised into the subaltern social structure, which makes individuals unable to change and exercise their agencies". ${ }^{74}$ Same applies to the second agency-related problem. Although the theory does not recognise it, accounting studies which apply structuration theory have clearly demonstrated vested interests of agents arising from their 'positions'. For example, in a structuration-inspired study, Lawrenson ${ }^{75}$ explains how the structure of the British railway engineering industry facilitated the dominance of engineers over accountants in controlling the industry.

Similarly, in the context of exploring resistance to accounting change within a division of a large multi-divisional firm, Scapens and Roberts" ${ }^{76}$ commented, "[i]t is important not to dismiss resistance to accounting change as illogical and emotional. Such resistance is probably informed by a whole variety of very real concerns and fears". ${ }^{77}$ We would argue that these 'real concerns' are linked with the real interests of agents occupying certain structural slots within an

\footnotetext{
732009.

${ }^{74}$ p.351.

751992.

761993.

${ }^{77}$ p.01.
} 
organisation or society. The same phenomenon of interests associated with structural positions is documented in Conrad's ${ }^{78}$ study of the UK gas industry.

The problems associated with the 'virtual' status of accounting are also evident in structurationbased papers. For example, in a study of the implementation of a new costing system in a hospital, Hassan ${ }^{79}$ explores how professionals, such as accountants and physicians, draw on their stocks of knowledge to influence emergent costing practices. However, in this context, it is debatable whether it can be claimed that stocks of knowledge of medicine and accounting exist only in the minds of agents: we are all aware that the bulk of this knowledge exists in books and journals. Nonetheless, as explained earlier, accepting the a priori and independent existence of knowledge means giving an independent ontological status to these ideas. However, this is a position that runs contrary to the basic tenets of structuration.

The second issue identified by Englund et al. ${ }^{80}$ and Englund and Gerdin ${ }^{81}$ from the review is the selective use of structuration concepts to demonstrate their 'usefulness' for accounting research. Based on the review of criticism of structuration theory, we contend that problems perhaps stem from the theory itself. The approach adopted by Giddens when it comes to engaging his theory with empirical situations is that Giddens ${ }^{82}$ selects other studies to illustrate some of his concepts of structuration rather than the other way round, i.e., using theory in a systematic way to explain empirical observations. ${ }^{83}$ For example, Giddens ${ }^{84}$ used Willis' ${ }^{85}$ 'Learning to Labour', a critical

\footnotetext{
782005.

792010.

802011.

812014.

821984

${ }^{83}$ Gregson, 1989.

${ }^{84} 1984$.

851977.
} 
ethnography, to illustrate the concepts of duality of structure. In Willis' ${ }^{186}$ case study, attitudes to work and school create 'counter school' actions by the lads and this in turn leads to the reproduction of working class 'culture'. According to Gregson ${ }^{87}$, none of the studies quoted by Giddens are based on structuration theory, meaning that these authors do not adduce structuration theories to explain the empirical evidence. Instead, Giddens adduces their empirical evidence to prove certain aspects of his theory. ${ }^{88}$

In reply to this criticism, Giddens suggests that researchers should use certain aspects of his theory selectively as a sensitizing device, rather than using the concepts en bloc. ${ }^{89}$ Contemporary sociologists are somewhat unconvinced about the use of sociological concepts as a sensitizing device. ${ }^{90}$ The problem with this concept of 'sensitizing' is that "finding out specifics of a situated process and assessing the validity of the attendant account are eschewed in favour of 'selectively looking for' traces of ontological concepts". ${ }^{91}$ The selective use of structuration theory concepts is thus an inevitable research strategy, adopted also by accounting researchers. Accounting researchers have used it at times to illustrate 'duality', ${ }^{92}$ and at other times, to explain the 'dialectics of control' ${ }^{93}$ Without discounting the benefits of using concepts as a sensitizing device, we agree with Englund and Gerdin's ${ }^{94}$ and Englund et al.'s ${ }^{95}$ observation that accounting researchers have not sufficiently engaged with the theory as a whole to generate new empirical and theoretical insights. However, we suggest, since the theory itself advances the idea of

\footnotetext{
861977.

871989.

${ }^{88}$ Gregson, 1989:242.

${ }^{89}$ Giddens, 1989:294.

${ }^{90}$ Stones, 2005.

${ }^{91}$ Stones, 2005:39.

${ }^{92}$ Macintosh and Scapens, 1990.

${ }^{93}$ Uddin and Tsamenyi, 2005

942014.

952011.
} 
sensitization using one or two concepts, it is inevitable that accounting studies would have followed suit.

We would like to acknowledge the fact that extensions of structuration theory advanced by Stones and Cohen have influenced some recent accounting studies ${ }^{96}$. Although this paper does not have space to discuss extensions of Giddens' work by other sociologists and their influence on accounting studies ${ }^{\mathrm{ii}}$, nevertheless, we feel some brief commentaries would be useful for the readers. One of the recent management accounting papers, Coad and Glyptis ${ }^{97}$ used a positionpractice perspective informed by Cohen's work for research in accounting and control. This perspective emphasises the link between the praxis of variously situated agents and the production and reproduction of social practices. As such, it gives greater prominence to praxis and positioning than has hitherto been evident in accounting and control research grounded in structuration theory. ${ }^{98}$ This paper, to some extent, attempted to address the criticisms of conflations attributed by critical realists. This is an interesting reading of Giddens by Cohen and Stones (as reflected in Coad and Glyptis) for critical realists. As they claim, there is no theoretical place for agents' motivation arising from their 'positions' in material structures in Giddens. If we were to accept the ontological status of 'position' or 'interests', this would go against the core spirit of duality championed by Giddens.

We find that extensions of structuration by Stones, perhaps to overcome the ontological divide between Giddens and Archer and bring the debate on the interplay between structure and agency forward (see Stones, 2001) has not had much influence on accounting research. We find only

\footnotetext{
96 Jack and Kholeif, 2007, 2008; Coad \& Herbert, 2009; Coad \& Glyptis, 2014

972014.

${ }^{98}$ Coad and Glyptis, 2014, p.142.
} 
two accounting studies so farii (since its introduction in accounting research in 2007), drawing on strong structuration theory by Stones (Jack \& Kholief, 2008; Coad \& Herbert, 2009), focused on duality (internal structure) while keeping dualism (for external structure) to explain management accounting changes. Nevertheless, Coad \& Herbert (2009) found it difficult to reconcile dualism and duality in their paper. They were critical of Stones' extensions of structuration theory attributing the lack of details regarding the complex interactions between external and internal structure that ignores the potential for a plurality of structures, and also the potential for agents to "do otherwise". Offering a comprehensive evaluation of Stones' structuration theory is beyond the scope of the paper. Nevertheless, it is suffice to say strong structuration theory has also been criticised by contemporary sociologists pointing out the problematic notion of duality (Parker, 2006; Elder-Vass, 2010). The following subsection provides what 'dualism', in particular, critical realism can contribute and offers some new insights in relation to management accounting change drawing on the C\&D's case study.

\section{A Critical Realist Framework: New Insights Possible?}

According to the critical realists, empirical events such as the budget row and its eventual outcome in C\&D's case study, cannot be understood without analysing the underlying structures. The job of the social analyst is to identify these structures, their ways of working, and their interaction with the agency of the actors involved. Otherwise, as Sayer ${ }^{99}$ claims: we may commit a classical common-sense mistake of ascribing to actors the actions which are actually being caused by the underlying structures. Sayer ${ }^{100}$ gives the example of mortgage officers' practice of not giving credit to potential borrowers whose ability to pay is suspect. This practice is supported by organisational rules that do not allow mortgage officers to extend credit to a particular type of

\footnotetext{
991992.

1001992.
} 
potential borrower. However, these rules, in turn, operate to cater to the interests of positions within a structure, i.e., the capitalists' interest of the maximization of profits. Seen in this light, the interests and powers of 'positions' within individual entities and organisations are rooted within the interests and powers of 'positions' within broad institutions that make up the social system. ${ }^{101}$ In modern day western societies, these broad institutions include religion, family, state, capitalism, and democracy. ${ }^{102}$ These positions, and their interests and powers, are created through the active efforts of agents.

So, in the case of University of Wisconsin, the governor's office and other state institutions form a structure, i.e., a set of internally related objects. Each object, e.g., the University of Wisconsin, comprises certain positions. These 'positions', e.g., those of the governor, university administrators, etc., endow the incumbents with some powers, vulnerabilities, and interests. The initial step in analysing the budget row involves understanding the powers, vulnerabilities and interests of those positions, which will push the incumbents of positions (agents) to act in a certain manner. For critical realists, these positions preceded their occupants. If we do not accept this material structural relationship, then the entire budgeting row may well be reduced to interpersonal conflict. However, once created, these positions should have an influence on the actions of the agents who occupy these positions. One of these effects of positions is to provide a motivation for some position holders to try and change the structures in place and for others to maintain the status quo. As explained earlier, organisational rules (e.g., budgeting rules) cater to the interests of some positions while they may frustrate the interests of some other position holders. The larger structural change in the form of the economic downturn created a situation in the University of Wisconsin such that the EFF-based budgeting rules were no longer serving the

\footnotetext{
${ }^{101}$ Friedland and Alford, 1987.

102 p.248.
} 
interests of position holders within the university administration, thus providing them with the motivation to change these rules. This is the structural part of the University of Wisconsin budget row analysis.

Next, the agential aspect of the analysis of the case will be discussed. Just because there are structural contradictions between the interests of positions creating motivation for certain position holders to try to change the organisational rules does not mean that an actual change will take place. This also requires a careful reflection on the situation and strategizing of agents. This is the moment of agency. According to critical realists, the first step in agential efforts to bring about a change involves a declaration of purpose by the agents. ${ }^{103}$ In the University of Wisconsin budget row, we see this in the following passage attributed to the President of the University: "Higher education in Wisconsin will require a return to the higher priority of the past. Additional state aid... will have to come from a shift in spending priorities by the governor's office and the legislature ... The traditional formula does not get at the root of the problem."104

The declaration of aim facilitates the organisation of agents whose interests are being affected by the existing structures and associated rules but are otherwise divided due to a host of reasons. ${ }^{105}$ It is apparent from the $C \& D$ case study that there were tensions among different campuses of the university about the internal allocation of funds across schools and campuses. Madison, a prestigious Wisconsin campus, felt that the funds that rightfully belonged to it were redistributed among other campuses while other campuses felt that Madison should show more magnanimity. Rejection of the EFF-based budget allowed administrators of all campuses to transcend their differences and work towards a common cause.

\footnotetext{
103 Archer, 1995.

${ }^{104}$ Covaleski and Dirsmith, 1988; p. 12.

105 Archer, 2000.
} 
For agents to bring about a change, they also need to devise a strategy including a 'calculation' of the risks involved. ${ }^{106}$ Agents operate in an environment of uncertainty where the consequences of their actions cannot be determined beforehand. This is where the critical realist analysis provides a richer explanation of the role of agency as compared to other theoretical accounts, which explain social changes in a structural and functional manner or perhaps through the enactment of unwritten mental scripts. ${ }^{107}$ In the University of Wisconsin case, we see these risks being taken by actors: "There is a strong undertone that lawmakers do not like to get into prioritization of education. The university knows it and likes it that way. They took a risk by giving distinct categories. But they were willing to take the risk to get out from under the enrolment formula."108

As explained earlier, according to critical realists, to bring about a change in organisational (budgeting) rules, agents occupying disadvantaged structural positions need to carefully craft strategies, including the calculation of risks and declaration of the aims for change. Moving forward, they need to use, not only the material means available, but also the symbolic resources at their disposal. The use of symbolic resources is important for galvanizing support from the larger segments of society, especially when the case involves a conflict with the state, which controls more material resources than any other institution in a modern society. ${ }^{109}$ The change in budgeting rules, thus required the use of symbolic resources by the university to legitimize the

\footnotetext{
106 Archer, 2000.

107 Sayer, 2000.

${ }^{108}$ Covaleski and Dirsmith, 1988; p 15.

${ }^{109}$ Weber, 1991.
} 
need for change. The university thus rationalized its demand for more money by invoking the logic that higher spending on education will lead to economic recovery of the state.

At the same time, it further justified this logic by universalizing it, i.e., 'Everyone else is doing the same': "We would be seriously remiss if we did not make economic recovery and vitality major themes of this budget request. No issue is more central to public discussion than this one. Clearly much has been done by the university to foster this goal. Yet recent studies also identify critical gaps and show areas in which further contributions could be made if additional resources were available. Recognising similar opportunities, other states have taken significant steps to fund additional university-based training and technology. It seems to us that the time has come for comparable initiatives in Wisconsin." 110

It is important to note that a critical realist account of agency is not simply a materialist account whereby the agents are pursuing their material interests. The same agents occupy various 'positions' within multiple structures with a possibility that the interests of various positions may be at odds with each other. A person occupying the role of a 'manager' in a firm may also be a 'member' of a religion, and the 'interests' of the two roles may oblige the person to act very differently towards his subordinates or fellow brothers in faith. One can understand that two structures may cause divergent tendencies within the same agent vis-à-vis the exercise of controls within an organisation. This opens up space for human agency, interpreting and 'weighing' structural conditions emanating not just from organisational structures (in the form of say pursuit of more 'profits') but also from other social structures (Boland, 1993). This power of agential interpretation of interpreting structural pressures is duly acknowledged by critical realists. According to critical realists, the structures that supersede others, in terms of shaping the

\footnotetext{
${ }^{110}$ Covaleski and Dirsmith, 1988; p. 13.
} 
behaviour of individuals in a specific situation, are an empirical matter and cannot be determined at the level of theory ${ }^{111}$. In any case, membership of different structures or the wider institutional arrangements allow the members to be aware of the different logics that govern these institutions and how they can use these to achieve their interests. ${ }^{112}$ While using the logic that higher spending on education will eventually lead to marketplace activity, the agents in $C \& D^{113}$ must be aware that there is an opposing market logic which suggests that if 'markets' do not support programs/campuses in terms of enrolments, these should be shut down ${ }^{\text {iv }}$. Creating three separate DINs was a carefully crafted strategy that not only allowed the university administrators to ask for more funds but also created the space for professional autonomy because these DINs could not be linked back to individual programs/campuses.

The 'interests' of educational professionals in maintaining professional autonomy generally results in the formulation of such strategies by them. ${ }^{114}$ The counter-action by state officials can also be seen through the prism of agency as explained through the critical realists. As compared to the university, the state officials (agents) have significantly more material means available to them due to their position ${ }^{\mathrm{v}}{ }^{115}$ In theory, they could reject or accept any budget form/proposal that comes from any institution including the university. However, in a modern society, state officials also need legitimacy for the use of their authoritative powers. This required the governor and other state officials to engage in 'budget games' described in C\&D's ${ }^{116}$ case study.

\footnotetext{
${ }^{111}$ Sayer, 2000.

${ }^{112}$ Seo and Creed, 2002.

1131988.

${ }^{114}$ Bacharach and Mundell, 1993.

115 Weber, 1991.

1161988.
} 
The critical realist analysis ${ }^{117}$ can thus explain the University of Wisconsin budget conflict and its outcome through analysing the underlying structures that caused the agents to act in a certain manner as well as the agency of actors. In a critical realist analysis, while the actors in the case used their interpretive frames, actions, and strategies to achieve the desired result, this interaction clearly did not take place in a structural vacuum. However, the existence of these prior material structures and their influence on the action do not play any role in structuration. ${ }^{118}$ Accepting the existence and effect of prior material structures on agency would have meant accepting the 'dualism' of structure and agency. The lesson that we can draw from a critical realist analysis of the University of Wisconsin budget row is that in order to avoid the issue of conflation, it is important that researchers should not focus exclusively on 'actions'. Any organisational accounting change research must look at the 'context' within which these actions or practices are taking place, including the social relations that necessitate the control of one group by the other. ${ }^{119}$ These 'social relations' are independent of and precede any accounting practices that are the subject of study. More importantly, these material relations have a conditioning effect on the nature of the accounting practices we encounter in an organisational setting.

It is also important to note that there is nothing virtual about accounting practices or accounting rules and regulations. Contrary to the approach suggested by structuration theory, where accounting has to be seen a virtual modality enacted at the time of action; it is much more fruitful to analytically separate the structural conditions from the day-to-day social interaction of organisational actors. These structural conditions provide agents with interests to either change

\footnotetext{
117 Sayer, 1992, 2000; Archer, 1995, 2001.

118 Archer, 1995.

${ }^{119}$ Armstrong, 2008.
} 
the structural conditions and corresponding management accounting practices ${ }^{120}$ or preserve the status quo ${ }^{121}$. Agents living within the structural matrix, then exercise their agency by trying to bring about the changes that suit their material and ideal interests ${ }^{122}$. At times they are successful in bringing about these changes and other times they are not ${ }^{123}$.

\section{Concluding Remarks}

We do not wish to argue that the structuration theory has not progressed in accounting research. Nor do we wish to argue that the structuration theory has not contributed to accounting, especially accounting change. Nevertheless, our focus is to critique fundamentals of structuration theory and offer an alternative way forward to incorporate the structural and agential aspects of accounting change/stability, especially management accounting change/stability. First, the paper extends the recent debate on the contribution of structuration theory advanced by review articles published in prominent accounting journals. Whilst recent evaluations have exposed a number of significant theoretical issues relevant to management accounting researchers, they have failed to reflect on the fundamentals of structuration. In the paper, we sought to demonstrate why accounting researchers could not get a better theoretical purchase out of structuration theory to illuminate the field of their inquiry as claimed by Englund and Gerdin. ${ }^{124}$ Second, the paper also sought to draw accounting researchers' attention to criticisms of structuration theory by

\footnotetext{
${ }^{120}$ Alawattage and Wickramasinghe, 2009

${ }^{121}$ Wickramasinghe and Hopper, 2005

${ }^{122}$ Ashraf and Uddin, 2013

${ }^{123}$ Broadbent et al., 2001

1242014.
} 
contemporary sociologists. More specifically, the paper extended the critique of structuration theory from a 'critical realist' perspective, in particular by demonstrating how these theoretical shortcomings manifest in management accounting research. Finally, by conducting an intensive examination of one of the most cited structuration-based accounting study, i.e., $M \& S^{125}$, the paper sought to highlight what accounting researchers who have embraced a structuration lens may have ignored. We argue that a critical realist account of C\&D's ${ }^{126}$ case study does provide a far more in-depth account of budgeting changes and is likely to avoid the problems that are encountered by using a structuration theoretical lens. ${ }^{127}$ We believe that through this analysis, we have broadened the current debate surrounding the achievements and limitations of structuration theory in accounting research as well as suggesting an alternative way of theorizing the accounting phenomena incorporating the role of structure and agency.

\footnotetext{
1251990.

1261988 .

${ }^{127}$ Englund and Gerdin, 2008, 2014; Englund et al., 2011.
} 


\section{References}

Alawattage, C. and Wickramasinghe, D. 2009. 'Weapons of the Weak: Subalterns' Emancipatory Accounting in Ceylon Tea'. Accounting, Auditing and Accountability 22(3): 379404.

Archer, M. 1982. 'Morphogenesis versus Structuration: On Combining Structure and Action'. British Journal of Sociology 33(2): 455-83.

Archer, M. 1995. Realist Social Theory: The Morphogenetic Approach. Cambridge University Press.

Archer, M. 2000. Being Human: The Problem of Agency. Cambridge University Press.

Archer, M. 2003. Structure, Agency and the Internal Conversation. Cambridge University Press.

Armstrong, P. 2002. 'The costs of activity management'. Accounting, Organizations and Society 27(1/2): 99-120.

Armstrong, P. 2008. 'Calling out for More: Comment on the Future of Interpretive Accounting Research'. Critical Perspectives on Accounting 19(6): 867-879.

Barley, R. S. and Tolbert, S. P. 1997. 'Institutionalization and Structuration: Studying the Links between Action and Institution'. Organization Studies 18(1): 93-117.

Baxter, J.J., Chua, W.F. 2003. 'Alternative Management Accounting Research - Whence and Whither'. Accounting, Organisations and Society 28 (2-3): 97-126.

Bhaskar, R. 1997. A Realist Theory of Science. London: Verso.

Bhaskar, R. 1979. Possibility of Naturalism. Hassocks: Harvester.

Boland, R.J 1993. 'Accounting and the Interpretative Act'. Accounting, Organizations and Society 18 (2/3): 125-46.

Broadbent, J., Jacobs, K. and Laughlin R. 2001. 'Organisational Resistance Strategies to Unwanted Accounting and Finance Changes: The Case of General Medical Practice in the UK'. Accounting, Auditing and Accountability Journal 14(5): 565-586.

Bryer, R.A. 2005. 'A Marxist Accounting History of the British Industrial Revolution: A Review of Evidence and Suggestions for Research'. Accounting, Organizations and Society 30(1): 25-65.

Burns, J. E. and R. W. Scapens 2000. 'Conceptualising Management Accounting Change: An Institutional Framework'. Management Accounting Research 11: 3-25.

Burrell G. and Morgan, G. 1979. Sociological Paradigms and Organizational Analysis. Heinemann.

Chenhall, R. H. 2003. 'Management Control System Design within its Organizational Context: Findings from Contingency-Based Research and Directions for the Future'. Accounting, Organizations and Society 28(2/3): 127-168. 
Conrad, L. 2005. 'A Structuration Analysis of Accounting Systems and Systems of Accountability in the Privatised Gas Industry'. Critical Perspectives on Accounting 16(1):1-26.

Coad, A and Herbert, I. 2009. 'Back to the future: New Potential for Structuration Theory in Management Accounting Research?'. Management Accounting Research 177-192.

Coad, A. and Glyptis, L. 2014. 'Structuration: A position-practice perspective and an illustrative study'. Critical Perspectives on Accounting 25(2): 142-161.

Covaleski, M. A. and M. W. Dirsmith. 1988. 'The Use of Budgetary Symbols in the Political Arena: An Historically Informed Field Study'. Accounting, Organizations, and Society 13(1): 124.

Covaleski, M.A., Dirsmith, M.W. 1986. 'The Budgetary Process of Power and Politics'. Accounting, Organizations and Society 11(3): 193-214.

Dent, J. F. 1991. 'Accounting and Organisational Cultures: A Field Study of the Emergence of a New Organisational Reality'. Accounting, Organizations and Society 16(8): 693-703.

Englund, H \& Gerdin, J. 2014. Structuration theory in accounting research: applications and applicability. Critical Perspectives on Accounting. 25 (2): 162-180.

Englund, H. and Gerdin, J. 2008. 'Structuration Theory and Mediating Concepts: Pitfalls and Implications for Management Accounting'. Critical Perspectives on Accounting 19(8): 11221134.

Englund, Hans, Gerdin, Jonas \& Burns, John 2011. '25 years of Giddens in accounting research: achievements, limitations and the future'. Accounting, Organizations and Society 36(8): 494513.

Giddens, A. 1976. New Rules of Sociological Method. London, UK: Hutchinson.

Giddens, A. 1979. Central Problems in Social Theory. London, UK: Macmillan.

Giddens, A. 1981. A Contemporary Critique of Historical Materialism. Berkley; University of California Press.

Giddens, A. 1984. The Constitution of Society. Cambridge, UK: Polity Press.

Giddens A. 1990. ‘The consequences of modernity'. Cambridge: Polity Press.

Granlund, M. 2001. 'Towards Explaining Stability in and Around Management Accounting Systems'. Management Accounting Research June: 141-166.

Gregson, N. 1989. 'On the (Ir)Relevance of Structuration Theory To Empirical Research'. In Social theories of Modern Societies: Anthony Giddens and his Critics, eds Held, D. and Thompson, J.B. Cambridge, UK: Cambridge University Press.

Elder-Vass, D. 2010. 'The Causal Power of Social Structures: Emergence, Structure and Agency'. Cambridge University Press.

Hassan 2010. 'Understanding the behavioural aspects of costing systems in public health organisations'. Int. J. of Behavioural Accounting and Finance 1(3): 207-223. 
Hopper, T. and P. Armstrong 1991. 'Cost Accounting, Controlling Labour and the Rise of Conglomerates'. Accounting, Organizations and Society 16(5/6): 405-438.

Hopwood, A.G. 1990. 'Accounting and Organisation Change'. Accounting, Accountability and Auditing Journal 3(1): 7-16.

Jack, Lisa \& Kholeif, Ahmed 2008. 'ERP and a contest to limit the role of management accountants: a strong structuration perspective'. Accounting Forum 32(1): 30-45.

Jack, L. \& Kholeif, A. 2007. 'Introducing Strong Structuration Theory for Informing Qualitative Case Studies in Organization, Management and Accounting Research', Qualitative Research in Organizations and Management: An International Journal, vol. 2, pp. 208-25.

Jayasinghe, K. and Thomas, D. 2009. 'The preservation of indigenous accounting systems in a subaltern community'. Accounting, Auditing \& Accountability Journal 22(3): 351-378.

Kakkuri-Knuuttila, Lukka, K. and Kuorikoski, J. 2008. 'Straddling between Paradigms: A Naturalistic Philosophical Case Study on Interpretive Research in Management Accounting'. Accounting, Organizations and Society 33(2/3): 267-291.

Kilfoyle E. and Richardson A.J. 2011. 'Agency and structure in budgeting: thesis, antithesis and synthesis'. Critical Perspectives on Accounting 22(2): 183-199.

Laughlin, R. 1991. 'Environmental Disturbances and Organizational Transitions and Transformations: Some Alternative Models'. Organization Studies 12(2): 209-32.

Lawrenson, D. M. 1992. 'Britain's railways: The predominance of engineering over accountancy during the inter-war period'. Critical Perspectives on Accounting 3(1): 45-60.

Macintosh, N. B. and Scapens R. W. 1990. 'Structuration Theory in Management Accounting'. Accounting, Organizations and Society 15(5): 455-477.

Modell, S. 2015. 'Making institutional accounting research critical: dead end or new beginning?' Accounting, Auditing and Accountability Journal (in press).

Mouritsen, J. 1999. 'The Flexible Firm: Strategies for a Subcontractor's Management Control'. Accounting, Organizations and Society 24(1): 31-55.

Outhwaite, 1987. 'New philosophies of social science: Realism, hermeneutics, and critical theory'. Hampshire: Macmillan Education.

Parker, J. 2006. 'Structuration's Future? - From 'All and Every' to 'Who Did What, Where, When, How and Why?' Journal of Critical Realism, 5 (1):122-138.

Porpora, D.V. 1989. 'Four Concepts of Social Structure'. Journal for the Theory of Social Behaviour 19(2): 195-211.

Roberts, J. and Scapens R. 1985. 'Accounting Systems and Systems of Accountability Understanding Accounting Practices in their Organisational Contexts'. Accounting, Organizations and Society 10(4): 443-456. 
Roberts, J. 2014. 'Testing the limits of Structuration Theory in Accounting'. Critical Perspectives on Accounting. 25 (2): 135-141.

Sayer, R. A. 1992. 'Method in Social Science: A Realist Approach'. 2nd Edition: London, New York Taylor \& Francis.

Sayer, R. A. 2000. 'Realism and Social Science'. London. Thousand Oaks: Sage Publications.

Scapens R. W. and Roberts, J. 1993. 'Accounting and control: a case study of resistance to accounting and change' Management Accounting Research 4(1): 1-32.

Scott, J. C. 1990. 'Domination and the Arts of Resistance: Hidden Transcripts'. New Haven: Yale University Press.

Seo, M.G. and Creed, W.E.D. 2002. 'Institutional Contradictions, Praxis, and Institutional Change: A Dialectical Perspective'. The Academy of Management Review 27(2): 222-247.

Sewell, W. 1992. 'A Theory of Structure: Duality, Agency, and Transformation'. American Journal of Sociology 98(1): 1-29.

Stones, R. 2005. 'Structuration Theory'. London: Palgrave.

Stones, R. 2001. 'Refusing the realism-structuration divide'. European Journal of Social Theory, 4, 177-197.

Thompson, J.B. 1989. 'The Theory of Structuration'. In Social Theory of Modern Societies: Anthony Giddens and his Critics, eds Thompson, J.B. and Held, D. Cambridge: Cambridge University Press.

Uddin, S.N and Hopper, T. M. 2001. 'A Bangladesh soap opera: privatisation, accounting, and regimes of control in a less developed country'. Accounting, Organizations and Society 26: 643672.

Uddin, S and Tsamenyi, M. 2005. 'Public Sector Reforms and the Public Interest: A Case Study of Accounting Control Changes and Performance Monitoring in a Ghanaian State-Owned Enterprise'. Accounting, Auditing and Accountability Journal 18(5): 648-674.

Weber, M. 1991. 'Politics as vocation'. In Essays in Sociology, eds Gerth, E. and Mills, J.R.

London: Routledge.

Wickramasinghe, D. and Hopper, T. 2005. 'A Cultural Political Economy of Management Accounting Controls: A Case Study of a Textile Mill in a Traditional Sinhalese Village'. Critical Perspectives on Accounting 16(4): 473-503.

Willis P. 1977. Learning to Labor: How Working Class Kids Get Working Class Jobs. Cambridge: Cambridge University Press.

Willmott, R. 2000. 'The Place of Culture in Organization Theory: Introducing the Morphogenetic Approach'. Organization 7(1): 95-128. 
${ }^{\mathrm{i}}$ Other recent examples of similar research include Kakkuri-Knuuttila et al. (2008) and Englund and Gerdin (2008), where the authors primarily analysed a single paper to contribute to important theoretical conversations in the field of accounting.

ii Issues of conflations have been debated and discussed in accounting studies and management accounting change (Burns and Scapens, 2000; Modell, 2014), we wish to remain focused on the theoretical debate between structuration and critical realism and its implicaitons for management accounting researchers. This has not been discussed in the accounting field.

iii Recently there is a call for special issue by Jack and Kholeif for a special issue of Accounting, Auditing and Accountability Journal on this particular theme.

iv " [I]n 1982 departing State Governor Lee Dreyfus warned that the UWS would be forced to close some of its campuses by economic pressures if it wanted to remain one of the nation's top academic systems. As he said, "It is clear that the University of Wisconsin will no longer be able to lead the nation if they decide to keep every institution". (Covaleski and Dirsmith, 1988; p 13"

${ }^{v}$ According to Weber (1991, p73), "a state is a political organization with a centralized government that maintains a monopoly over the legitimate use of force within a certain territory". 